\title{
Financial Performance Analysis of PT. Bank Papua: Application of Cael, Z-Score and Bankometer
}

\author{
Anita Erari ${ }^{1}$. Ubud Salim², M. Syafie Idrus ${ }^{3}$, Djumahir ${ }^{4}$ \\ ${ }^{1}$ Faculty of Economics, Cenderawasih University, Jayapura-Papua-Indonesia. \\ ${ }^{2,3,4}$ Faculty Of Economics And Business, Brawijaya University, Malang-East Java-Indonesia
}

\begin{abstract}
This study aims to analyze the precision and accuracy of financial ratio analysis model by using CAEL, Z-score and Bankometer in assessing the financial performance development of Bank Papua within the period from 2003 to 2011. The results show that the model CAEL and Bankometer give the same assessment that Bank Papua, from 2003 to 2011, had good wellbeing, was highly liquid, had strong capital, were able to manage debt well, had good profitability, and asset quality but was still lacking in efficiency. Z-score model reversely put Bank Papua in a grey area and went bankrupt in 2007 and 2011, weak liquidity and capital. These findings reinforce previous research which suggests that Z-score model is not appropriate to be used in banking, however, the use of Z-score is recommended as the dissenting opinion and early warning system in assessing financial performance of a bank, because it can correctly show critical points in financial management of a bank. The similarity of the analysis results of the three models above is that Bank Papua has good profitability.
\end{abstract}

Keywords: Financial Performance, CAEL, Z-score, Bankometer

\section{Introduction}

In the period from 2000 to 2011, we have witnessed a wave of bankruptcies swept the giant companies which is because of the scale, they had not been predicted to go bankrupt. Companies like General Motors, Lehman Brothers, WorldCom, Enron and Conseco are giant companies with billions dollars of assets and extraordinary financial performance so that they were to be the center of the world management and the success was as reference materials in various business education institutions. But then they also had a very bad fall so that they always fall and give examples to the world that no matter how big the company is, it can still go bankrupt if it is not managed properly.

Among the five companies, two companies; Enron and Lehman Brothers' had downfall so extraordinary so that it is hard to believe and this giant bankruptcies will remind people of the two companies. First, Enron went bankrupt in 2002, is an energy company based in Houston and is the result of a merger between the company Internorth and Houston Natural Gas in 1985. Enron grew rapidly and recorded revenue of 101 billion dollars in 2000, so that by Fortune magazine awarded the title of "America's Most Innovative Company" for six consecutive years in April 2001. Nevertheless, six months after entitling the "America's Most Innovative Company", Enron bankruptcy was later reported on 30 November 2001 and applied for bankruptcy protection on the $2^{\text {nd }}$ of December 2001. Enron was subsequently declared bankrupt in 2002, leaving debts of 31.2 billion dollars.

The second company is Lehman Brothers which was the fourth largest investment bank in the United States with a very long history that was begun as cotton trading company established in 1850 in Alabama. In 2007, Lehman Brothers was named as the best-managed firms on Wall Street but on the $15^{\text {th }}$ of September 2008, it had to file for bankruptcy protection chapter 11 of bankruptcy laws in the United States in order to avoid the possibility of being liquidated and bankrupt, leaving total assets of 639 billion dollars and the total debt amounting at 613 billion dollars as a result it was noted as the largest bankruptcy in U.S. history.

Both bankruptcy histories above show that a company with excellent management, outstanding financial performance and able to grow very rapidly without any financial distress symptoms, in fact it can be turned out to be a sudden bankruptcy. It often happened in history, even companies that show symptoms of financial hardship such as inability to pay dividends, had a negative cash flow or the amount of profit that is not able to cover interest charges are able to survive and do not experience bankruptcy.

PT. Regional Development Banks (Bank Papua) is one of regional banks that has a very rapid growth in recent years, thus gaining numerous rewards from national media. Even Infobank magazine in 2011 awarded Platinum Trophy 2010 to Bank Papua as it is considered as a Bank with financial performance predicate of "Very Good" for 10 consecutive years from 2001 to 2010. Rapid growth of Bank Papua was seen also from the expansion of their business which is no longer only concentrated in Papua but also has opened several branch offices outside of Papua such as Jakarta, Surabaya, Makassar and Palopo. 
Referring back to the Enron and Lehman Brothers that were considered very good so it was impossible to be failed but then went bankrupt, showing that companies operate in uncertain environment that always changes so that what becomes the strength in a company at this time could be a weakness in the future. Therefore we need an analysis tool which is capable of showing weakness when the company is no longer the same within the environment, in order to take anticipatory measures that are able to release the company from the possibility of experiencing financial distress and even bankruptcy.

\section{Literature Review}

Altman (1968) conducted the first study to examine the use of financial ratio analysis as a tool to predict corporate bankruptcy by using discriminant analysis. Altman model has a high accuracy of the model of $90 \%$ in correctly classifying the bankrupt firms and $80 \%$ accurate in predicting the next financial difficulties. However, the use of Z-score models in banking had shown inaccuracies up to $70 \%$ or in other words the model Z-score early it is not accurate in predicting the likelihood of financial distress in the banking industry. Therefore Altman then revised the initial model and introduce Altman's four-variance model (Altman, 2000).

Altman Z-Score model has been used by many researchers to assess the probability of a company experiencing financial distress. Rahmat (2002) conducted a study by applying the Z-Score model to assess the financial performance of banks in Indonesia in 1995-1997 before they were declared bankrupt by Bank Indonesia. Pongsatat, et al. (2004) applied Ohlson's logit model and Altman's four-variance model to assess the financial performance and the possibility of financial distress at small and large companies in Thailand. Christopoulos et al. (2009) used Altman model to predict the likelihood of bankruptcy and concluded that Altman model was able and accurately identify sample the corporate financial difficulties. Altman model was more useful than traditional financial analysis. Endri (2009) applied the model of Altman in Islamic banking by using data from 2005 to 2007. Duvvuri (2012) applied Z-Score model to determine the corporate health of The Nagarjuna Fertilizers and Chemicals Limited after briefly experiencing financial difficulties in 2001

Some studies, especially those conducted in the banking industry conclude that the model of Altman ZScore (first model and last revised model) was less appropriate when it was used to assess the performance of a bank, both commercial banks and Islamic banks (Rahmat 2002, Endri 2009). This was mainly because the ZScore model was formed from empirical studies of manufacturing industry that would have strongly different characteristics from banking industry. This assessment, coupled with the decision of the Committee Basel I in 1988 in adopting the CAMEL model as the standard model of bank rating, made a lot of researchers who then used the CAMEL model as primary measurement tool in assessing the health condition of a bank.

Research by using CAMEL was conducted by several researchers such as Thomson (1991) who used to assess the CAMEL model to assess banks that faced failure in the 80's and concludes that CAMEL ratios can accurately predict the possibility of failure in a bank so it can be used as an early warning system in the banking industry, Manoj (2010) and Reddy S. (2012) who applied CAMEL ratio between the Bank in India, Mylonakis, et al. (2011) who used the CAMELS ratios to reassess the bankruptcy of Lehman Brothers. Prassad and Ravinder (2012) applied CAMEL by averaging each variable and the analysis results show that Andhara Bank is the best bank in India followed by Bank of Baroda and Punjabh \& Sindh Bank.

In Indonesia, some studies that use CAMEL to assess the financial performance of the banking industry, are such as Wilopo (2001), using the CAMEL to predict the financial difficulties that led to the bankruptcy of banks in Indonesia, Haryati (2001), seeking to analyze the financial performance of the bank's with type A, B and C by using financial ratios and Luciana and Winny (2005), using the ratio of CAMEL to predict problematic conditions in the banking institutions in the period of 2000-2002.

The results of the study using CAMEL to assess the financial condition and the health condition of banks in general conclude that CAMEL ratios are able to accurately show the condition of the troubled and untroubled banks but it cannot be used to predict the likelihood of a bank in experiencing financial distress or even bankruptcy. This weakness then is to be recovered to overcome the problem by some researchers to use the CAMEL analysis model and Z-Score analysis model to assess the financial condition of the Bank.

Zeny and Murtanto (2002) tried to predict the bankruptcy of a bank by analyzing financial statements and applying the CAMEL ratios and Altman model. From these studies, it can be concluded that there are two types of ratios that affect the most on failure rates which are the ratio of banks asset quality and capital ratios. Altman bankruptcy prediction analysis supports CAMEL model by categorizing the bankrupt banks that are considered unhealthy and quite healthy. While banks are categorized according to the ratio of CAMEL healthy, stay healthy because it can be said Altman results indicate circumstances that led to the Grey Area. Nurhidayah (2003) assessed the level of health and predict the possibility of financial distress of companies and banks listed on the Stock Exchange by implementing CAMEL ratios and Altman Z-Score model. Her study concluded that there are differences in the rating of health level and the possibility of financial distress from the two models, so it is still necessary some adjustments to be applied in banking industry. 
Using Z-Score analysis model and CAMEL together was not able to produce the same conclusion as the results tend to be different even contradictory judgments. Therefore in 2010, a model similar to Z-Score analysis specific to banks was intorduced, which is derived from the recommendation of IMF about the assessment of banks called Bankometer (S-Score). Shar, et al. (2010) applied Bankometer at any bank in Pakistan in 1999-2002 analysis period and the results compared with CAMEL ratio and CLSA-stress test. This study shows that there is no significant difference in the results shown by those three models and Bankometer model has the ability to predict the possibility of bank insolvent relatively the same with the two other analysis models.

Makkar and Singh (2012) assessed the level of solvency in commercial banks in India in the period of 2006/2007 - 2010/2011 by using Bankometer developed under IMF guidance on the bank rating, because it was assumed that it would be better to use traditional way by implementing CAMEL ratios and CLSA-stress test. The results explained that by applying Bankometer model, it can provide assessment of the accurate ability of the bank, so it is advisable for internal management to use Bankometer model in assessing the health of banks in India.

Referring back to the description of the three models above, it can be clearly seen that the analysis of the three models each have advantages and disadvantages. Some researchers use more than one model analysis together with the aim at providing more accurate and comprehensive analysis. This is in line with the opinion of Sawir (2005) and Salim (2011) who said that to see how much potential in company's health, in addition to Zscore (Altman), the company may choose one or a combination of models to assess the its health condition or detect the possibility of financial difficulties, then proceed with the analysis of financial reports to know, which part of the financial statements to watch and to be further investigated, in order to avoid cases of financial distress that led to the failure of company.

\section{Research Objectives}

1. To analyze the accuracy of financial ratio of Z-Score model (Altman's four-variance model) in assessing the financial condition of PT. Bank Papua.

2. To analyze and explain the ability of financial ratios Bankometer model to assess the financial condition of PT. Bank Papua.

3. To measure and analyze the precision and accuracy of Z-Score model and Bankometer model in assessing the financial condition PT. Bank Papua compared to the assessments by CAEL model.

\section{Research Methodology}

This research is a study to determine the quality of asset growth in PT. Bank Papua over the last nine years, especially after Papua Province is declared to have special autonomy status given by the Central Government. In addition, this study also aims to compare the prediction models of financial distress that has been widely used, which model is the most appropriate to be used in assessing financial performance of a bank, and what factors that affect the model is accurate or not. This is a descriptive study which illustrates the performance of Bank Papua and the accuracy of Z-Score model and Bankometer in assessing the financial condition of Bank Papua and reasons behind the accuracy or inaccuracy of the model. The data used are secondary data from financial statements (Balance Sheet and Income Statement) in 2003-2011.

\section{Method of Data Analysis}

1. Determining the predicate of Bank Papua by category CAEL ratios which are: Healthy $=56-75$; Quite healthy $=41<56$; Less healthy $=26<41$ and Unhealthy $=0<26$. (CAMEL maximum score $=100$; maximum score of this study is 75 since it is subtracted by Management score in CAMEL for 25).

2. Calculating the value of Z-Score and determine the bankruptcy criteria of PT. Regional Development of Bank Papua by using Altman models:

Where: $\mathrm{X} 1=$ Net Working Capital to Total Assets

$$
\mathrm{Z}=6.56 \mathrm{X} 1+3.26 \mathrm{X} 2+6.72 \mathrm{X} 3+1.05 \mathrm{X} 4
$$

$\mathrm{X} 2=$ Retained Earnings to Total Assets

$\mathrm{X} 3$ = Earnings before Interest and Tax to Total Assets

X4 = Market Value of Equity to Book Value of Debt

This condition can be seen from the Z-Score value. If:

a) The Z-score which is less than or equal to 1.23 means that the company is experiencing financial difficulties and high risk.

b) The score of $1.23<\mathrm{Z}<2.90$ then the company is considered to be in the grey area.

c) With the score of $Z>2.90$, it provides an assessment that the company is in a very healthy condition. 
3. Calculating the value of S-Score and position of the bankruptcy PT. Regional Development of Bank Papua by using Bankometer model:

Where: $\mathrm{X} 1=\mathrm{CA}$ or Capital Asset Ratio

$$
\mathrm{S}=1.5 \mathrm{X} 1+1.2 \mathrm{X} 2+3.5 \mathrm{X} 3+0.6 \mathrm{X} 4+0.3 \mathrm{X} 5+0.4 \mathrm{X} 6
$$

$\mathrm{X} 2=\mathrm{EA}$ or Equity to Asset

$\mathrm{X} 3=\mathrm{CAR}$ or Capital Adequacy Ratio

$\mathrm{X} 4=\mathrm{NPL}$ or non-performing loans to Loans

$\mathrm{X} 5=\mathrm{CI}$ or Cost to Income

$\mathrm{X} 6=\mathrm{LA}$ or Loan to Asset

2. With criteria:

a) For the value of $\mathrm{S}<50$ means that the company is experiencing financial difficulties and high risk.

b) For the value of $50<\mathrm{S}<70$ then the company is considered to be in the gray area (gray area).

c) For $\mathrm{S}$ greater than 70 , provide an assessment that the company is in a very healthy state.

4. Comparing the analysis results of CAEL, Z-Score and S-Score to get the most appropriate model to predict the financial condition of PT. Regional Development of Bank Papua.

\section{CAEL Model}

\section{Results And Discussion}

In the analysis of CAEL ratios, health or financial performance of Bank Papua is assessed from capital, asset quality, earnings ability and liquidity, as shown in Table 1.

Table 1

Calculation results CAEL Bank Papua 2003 - 2011

\begin{tabular}{|c|c|c|c|c|c|}
\hline Year & Capital & Assets & Profitability & Liquidity & CAEL \\
\hline 2003 & 25 & 27.62 & 6.49 & 10 & 69.11 \\
\hline 2004 & 25 & 26.57 & 6.58 & 10 & 68.15 \\
\hline 2005 & 25 & 27.22 & 6.32 & 10 & 68.54 \\
\hline 2006 & 25 & 27.37 & 6.41 & 10 & 68.78 \\
\hline 2007 & 25 & 27.78 & 6.85 & 10 & 69.63 \\
\hline 2008 & 25 & 28.25 & 6.82 & 10 & 70.07 \\
\hline 2009 & 25 & 27.83 & 6.89 & 10 & 69.72 \\
\hline 2010 & 25 & 29.25 & 6.83 & 10 & 71.08 \\
\hline 2011 & 25 & 29.02 & 6.91 & 10 & 70.93 \\
\hline
\end{tabular}

CAEL analysis results indicate that Bank Papua during the period of 2003 to 2011 is a healthy bank and has a very stable growth as seen from CAEL scores which show a tendency to increase steadily. If they are diffused by the components, it shows that the main strengths laid in Bank Papua are on the excellent capital and liquidity aspects so that for the past nine years has been always reached the maximum value obtained, which are 25 and 10.

Capital components is a major force in Bank Papua, it can be seen from the table that the CAR value has always been above $20 \%$, with significant range above the Bank Indonesia regulation, which requires capital adequacy (CAR) of $8 \%$. This seems closely related to the goal of Bank Papua to become Anchor Bank as appropriated by Indonesian Banking Architecture.

In terms of assets, Bank Papua asset quality can also be classified very well to be seen from the calculation of assets component value average which gains 27 points of possible maximum score of 30 . Assets are assessed based on the ratio of the two NPL ratios and PPAP compliance ratios. From both these ratios, the ratios of PPAP or KAP II are able to achieve maximum value because PPAP reserved by Bank Papua has been more than $100 \%$, or in other words, the backup created is greater than the amount of non-performing loans in Bank Papua. Asset value less than the Bank of Papua for the overall NPL ratio is still above the maximum limit of $0.5 \%$ which is required by Bank Indonesia to obtain a score of 100 or maximum value.

Profitability aspect is the weakest components of the CAEL calculation of Bank Papua. If aspects achieved are minimum $90 \%$ of the maximum value, then profitability aspect on average can only reach maximum $65 \%$ of the maximum value. If the disaggregated components of earnings, namely ROA and BOP, it is seen that BOPO ratio the major weakness since averagely it can only reach 1.65 of the maximum value of 5 while ROA is able to achieve maximum score of 5 out of 5 . This suggests that the Bank Papua's operations activities have not been very efficient in utilizing its resources to generate income. 
Last aspect is liquidity aspects measured by using LDR ratio or the ratio between the numbers of loans given to the number of third-party funds that have been collected. Based on the analysis of CAEL, this aspect is one of the main strengths of Bank Papua to reach a value of 10 out of a maximum of 10 can be obtained. Nevertheless, the strength of this ratio also eventually shows major, which is the inability of Bank Papua to act as agents of development in redistributing the funds back into the community in the form of loans. LDR average for nine years was $36.11 \%$, it means that there is only about $36 \%$ of the funds collected can be redistributed back in the form of loans. Thus, using only partial CAEL models analysis, it can be concluded that Bank Papua is a very healthy bank in the period 2003 to 2011 and free from the possibility of experiencing financial distress.

\section{Z-Score Model Assessment}

Z-Score model was originally formed for manufacturing firm so that many times it was considered to be not applicable for non-manufacturing firms. In 2002, Altman revised the old Z-Score model and produce a new model to accommodate companies whose fixed assets are not productive assets of the formula $\mathrm{Z}=6.56 \mathrm{X} 1$ $+3.26 \mathrm{X} 2+6.72 \mathrm{X} 3+1.05 \mathrm{X} 4$. This model is used by Bank Papua.

\section{Table 2}

Calculation of Z-Score Bank Papua 2003 - 2011

\begin{tabular}{|c|c|c|c|c|r|}
\hline Z-Score & 6.56 & 3.26 & 6.72 & 1.05 & \\
\hline & & & & & \\
\hline Year & $\mathbf{X 1}$ & $\mathbf{X 2}$ & $\mathbf{X 3}$ & $\mathbf{X 4}$ & Z-Score \\
\hline 2003 & 0.2094 & 0.0421 & 0.0296 & 0.1437 & 1.8609 \\
\hline 2004 & 0.1968 & 0.0369 & 0.0256 & 0.1260 & 1.7151 \\
\hline 2005 & 0.2383 & 0.0273 & 0.0187 & 0.1009 & 1.8838 \\
\hline 2006 & 0.1714 & 0.0191 & 0.0163 & 0.0613 & 1.3608 \\
\hline 2007 & 0.1211 & 0.0260 & 0.0211 & 0.0751 & 1.0999 \\
\hline 2008 & 0.1457 & 0.0385 & 0.0332 & 0.1036 & 1.4133 \\
\hline 2009 & 0.1798 & 0.0436 & 0.0326 & 0.1216 & 1.6684 \\
\hline 2010 & 0.2052 & 0.0453 & 0.0280 & 0.1286 & 1.8173 \\
\hline 2011 & 0.0969 & 0.0455 & 0.0286 & 0.1238 & 1.1060 \\
\hline
\end{tabular}

The results of Z-Score calculation of Bank Papua in 2003-2011 are under 2.90 and above 1.23, therefore it can be concluded that Bank Papua is categorized in Grey Area with the exception of 2007 and 2011 where the Z-Score are at 1.0999 and 1.1060 , or less than 1.23 so that it is bankrupt area.

Variable X1 or net working capital to total assets ratio shows that there are very large fluctuations without any particular trend, although the number of loans and the amount of third-party fund in Bank Papua continues to increase. This can happen especially since the calculation of net working capital is not solely influenced by the amount of third-party fund itself but mainly by the composition of each component consisting of Current Account, Savings, and Deposits.

Fluctuations of variable X1 is strongly influenced by the components of current account deposits as they are as the third-party fund components that are highly liquid, so it affects the calculation of net working capital. Variables X1 moves oppositely to the movement of current accounts, when the percentage of current account component is greater, so the value of variable $\mathrm{X} 1$ is getting smaller, reversely, when the percentage of current account in third-party fund components gets smaller, then the value of variable X1 becomes greater.

Variable X2 measures the ratio of retained earnings to total assets and shows a tendency to increase constantly, suggesting that the ability of Bank Papua to create income and generate profits is getting better. It is also in line with the trend of variable X3 which is EBIT divided by total assets, it also shows an increase in value. This means that every year there is an increase in EBIT or net income greater than the increase in total assets.

Variable X4 measures the ratio of equity book value and debt book value and show a declining trend due to the growing number of liability each year is greater than the growth in equity book value. The largest decrease occurred in 2006 when the total debt increased mainly from third-party fund more than doubled. After 2006 , the value of variable X4 was back up slowly because the increasing of third-party fund did not happen in sudden again as happened in 2006.

In general, the results of calculations using Z-score that predicate Bank Papua in Grey Area and even Bankruptcy Area are highly different from the results analysis that puts the ratio CAEL Bank Bank of Papua as a healthy and highly liquid. This discrepancy is mainly due to the Z-Score model formed from manufacturing 
firms that have different business characteristics with the banking industry. This analysis reinforces researches by Hayati (2002), and Zeny and Murtanto (2002), Hadad et al. (2004) and Endri (2009).

Characteristics of the banking industry as financial intermediary are very different from the characteristics of manufacturing firms. By having these functions, a bank has huge current liabilities originating from third-party. So the value of net working capital is relatively small. In addition, Bank Papua as the object of this study has not been go-public, therefore in the calculation of market value of equity is adjusted to book value of equity, by looking at the book value of equity (paid-in capital) Bank Papua which is relatively small and tends to keep its value every year. Therefore, calculations using the model Z-Score are less suitable for the banking sector including Bank Papua since the final prediction resulted is less accurate to describe the condition of the actual banking.

However, the calculation of Z-Score in 2007 and 2011 that result Bank Papua in the bankruptcy are has demonstrated the critical points in the management of Bank Papua in focusing more on current account growth as the main component of third-party fund. In 2007 and 2011, the number of current account in Bank Papua are the greatest amount along with the track record and even it was more than doubled of saving and deposit merged together. This can be risky because current account is the component of third-party fund that is very liquid so if it is withdrawn in once, it can cause liquidity problems for Bank Papua.

Additionally, third-party fund component that is dominated by current account also complicates Papua to perform to its full potential of fund placement because it always have to speculate on the possibility of large amounts withdrawn that can be done any time along with the nature of current account. Directly, this fact can be seen in the comparison between the amount of credit and third party funds that have never passed $50 \%$. This condition can be interpreted as a policy of Bank Papua to be speculative against the conditions of its third-party funds which are dominated by current account.

Therefore, although it is not very precise with CAEL calculation, the use of Z-Score is still needed to find critical points in bank management. This is in line with the opinion of Sawir (2003) who states that the purpose of Z-scores calculation is for the reminder of the financial problems that may require serious attention and provide guidance for action.

\section{Bankometer Model Assessment}

Bankometer model developed from the IMF recommendations in 2000 concerning restrictions on the assessment of a bank that is similar to CAEL ratio limitation set by Bank Indonesia. Thus Bankometer can be regarded as a model that is designed to obtain calculation automatically and replaces CAEL assessment process which is usually done manually by weighting. Thus, the results should be analyzed through Bankometer do not significanlty with CAEL analysis. The model is $\mathrm{S}=3.5 \mathrm{CAR}+1.5 \mathrm{CA}+1.2 \mathrm{EA}+0.6 \mathrm{NPL}+0.3 \mathrm{CI}+0.4 \mathrm{LA}$.

Table 3

Calculation results Bankometer Bank of Papua 2003-2011

\begin{tabular}{|c|c|c|c|c|c|c|c|}
\hline Banko- & $\mathbf{1 . 5}$ & $\mathbf{1 . 2}$ & $\mathbf{3 . 5}$ & $\mathbf{0 . 6}$ & $\mathbf{0 . 3}$ & $\mathbf{0 . 4}$ & Final \\
\hline meter & $\mathbf{X 1}$ & $\mathbf{X 2}$ & $\mathbf{X 3}$ & $\mathbf{X 4}$ & $\mathbf{X 5}$ & $\mathbf{X 6}$ & Score \\
\hline Year & $\mathbf{C A}$ & $\mathbf{E A}$ & $\mathbf{C A R}$ & $\mathbf{N P L}$ & $\mathbf{C I}$ & $\mathbf{L A}$ & S-Score \\
\hline 2003 & 13.70 & 8.07 & 24.01 & 1.93 & 50.79 & 38.28 & 145.98 \\
\hline 2004 & 12.16 & 7.26 & 22.73 & 2.56 & 53.13 & 32.41 & 136.93 \\
\hline 2005 & 9.91 & 5.90 & 30.62 & 2.17 & 56.66 & 24.21 & 157.10 \\
\hline 2006 & 6.33 & 3.59 & 34.80 & 2.08 & 51.04 & 14.88 & 158.12 \\
\hline 2007 & 7.58 & 4.19 & 35.52 & 1.83 & 58.06 & 17.33 & 166.17 \\
\hline 2008 & 10.26 & 5.53 & 55.97 & 1.55 & 56.33 & 22.96 & 244.94 \\
\hline 2009 & 11.66 & 6.48 & 46.73 & 1.80 & 53.52 & 28.87 & 217.50 \\
\hline 2010 & 12.03 & 6.86 & 23.25 & 0.95 & 55.96 & 34.00 & 138.61 \\
\hline 2011 & 11.47 & 5.91 & 23.54 & 1.09 & 53.42 & 38.18 & 138.64 \\
\hline
\end{tabular}

S-Score calculations above yield S values from 2003 to 2011 which are strongly above the limit of at least 70, therefore it can be interpreted that Bank Papua during the period is always in the category of healthy and does not experiencing financial distress. The calculations show a tendency to fluctuate, nevertheless because of the whole number of calculation results are strongly above the value of 70 which is as safe limit, the fluctuations will not have any significant impact on the health condition of Bank Papua.

The high value of S-Score Bank Papua is mainly influenced by the high capital adequacy rate or CAR (variable X3). CAR in Bank Papua from 2003 to 2011, even at the lowest of 22.73\% in 2004, they remain 
significantly above the limit of Bank Indonesia which is $12 \%$ and the IMF limit is $8 \%$ so it can be said that in terms of capital, Bank Papua is highly safe.

CA or Capital to Asset Ratio measures how much assets are financed either by equity or long term debt, the greater the ratio means that the bank is more secure because the assets are financed by long term funds. According to the IMF hint, the minimum limit for this ratio is 4\%. The ratio of CA in Bank of Papua from 2003 to 2011 are at the lowest, which is at $6.33 \%$ in 2006 and this means it is still higher than the minimum prescribed by the IMF. Equity to Asset Ratio or EA measures how many assets are financed by equity capital. The higher this ratio, the more secure the financial position of the bank in the long run because the more assets are financed by the bank's capital and is less dependent on external funding. According to the IMF, this ratio must be greater than 2\%, while the position of Bank Papua at the lowest position is $3.59 \%$ in 2006, still higher than the minimum limit of $2 \%$.

NPL is a ratio that shows how much the loan is classified as non-performing loans. Problematic here means the payment of interest has been delayed for more than 90 days. The higher this ratio indicates the higher non-productive loans given by a bank. IMF imposes limits that this ratio should be below $15 \%$, while Bank Papua NPL ratio at the highest is $2.56 \%$ in 2004, still far from the boundary so that the credit quality of Bank Papua can be classified as very well.

Cost to Income Ratio or $\mathrm{CI}$ is the ratio that compares the operating expenses excluding non-cash expenses and operating income hence it is something like the BOPO ratios of Bank Indonesia. The differences are when BOPO use total operational costs excluding interest and reserve formation expenses. The lower the ratio, the higher the level of bank profits so that IMF provides limits that this ratio should be lower than $40 \%$. The results of the calculation of the CI ratios in Bank Papua are still above 40\%. It indicates that Bank Papua has not been very efficient in carrying out its operations.

LA ratio measures the amount of assets invested in long-term credit. The higher ratio means more loans that will give positive impact on bank earnings but also give negative impact on bank liquidity, whereas the smaller ratio means fewer loans and hence it gives bad impact for bank earnings yet good impact on the liquidity of the bank. IMF imposes limit that this ratio should be lower than 65\%, while Bank Papua highest ratio is $38 \%$ so it can be concluded that the Bank of Papua highly liquid.

\section{Comparison of Each Model}

The results of an analysis of Bank Papua based on CAEL, Z-Score and S-Score method which are summarized in Table 4.

Table 4

Comparison of results of calculation of CAEL, Z-Score and S-Score

\begin{tabular}{|l|l|c|c|c|}
\hline No & \multicolumn{1}{|c|}{ Description } & CAEL & Z-Score & S-Score \\
\hline 1 & Health Condition & Highly Liquid & $\begin{array}{l}\text { Grey Area, Bankruptcy } \\
\text { Area in 2007 and 2011 }\end{array}$ & $\begin{array}{c}\text { Healthy } \\
\text { Solvent }\end{array}$ \\
\hline 2 & Trend & Increase & Fluctuated & Fluctuated \\
\hline 3 & Determining Factors & Nothing & Net Working Capital & CAR \\
\hline 4 & Capital & Strong & Weak & Strong \\
\hline 5 & Profitability & Good & Good & Good \\
\hline 6 & Liquidity & Liquid & Critical & Liquid \\
\hline 7 & Efficiency & Weak & - & Weak \\
\hline 8 & Assets Quality & Good & - & Good \\
\hline
\end{tabular}

Source: data processed 2012

From the summary of the analysis above, it can be described that the analysis application of CAEL, ZScore and S-Score at Bank Papua give the following results:

1. CAEL model analysis and S-Score analysis give the same results, Bank Papua from 2003 to 2011 is in good health, highly liquid, has strong capital, able to manage debt well, has good profitability, asset quality has but still lacks in efficiency. Instead of it, Z-Score analysis results as opposed to put Bank Papua in a position of Grey Area even threatened to Bankruptcy Area in 2007 and 2011, is illiquidity and weak in capital. The only similarity is that all the three methods together state that Bank Papua has the ability in generating good profitability.

2. Although the results are different from the other two models, Z-Score analysis is capable of pinpointing the critical situation faced by Bank Papua in 2007 and 2011 when the current account as third-party fund component which is highly liquid, the numbers have increased by nearly $70 \%$ of the total third-party fund that have been successfully collected by Bank Papua.

CAEL analysis model is the model used by Bank Indonesia to assess the health condition of banks in Indonesia, so this model is as the benchmark for the accuracy of other models. Among the two remaining 
models, S-Score model gives the same result with CAEL model which offers simpler and easier calculations techniques than CAEL calculation techniques so that S-Score can be used as a replacement for CAEL model in assessing the bank. The opposite of S-Score, Z-Score analysis gives vastly different results even contrary to the results of CAEL model analysis. Therefore, Z-Score is not appropriate at all in substituting CAEL model analysis in determining the health condition of a bank. However, the use of Z-Score has actually managed to uncover critical points in the management of Bank Papua that it is not successfully revealed by the other two models analysis.

Advantages and disadvantages of each model analysis are summarized in Table 5 below.

Table 5

CAEL Comparative Analysis Model, Z-Score and Bankometer

\begin{tabular}{|c|c|c|}
\hline Model & Advantage & Disadvantage \\
\hline CAEL & $\begin{array}{l}\text { 1. This model is required by the } \\
\text { Regulator and applies } \\
\text { universally so much easier to be } \\
\text { compared. } \\
\text { 2. This model is well standardized } \\
\text { so it does not cause any } \\
\text { confusion. } \\
\text { 3. Divided into five categories of } \\
\text { assessment so it is easy to see } \\
\text { the strengths and weaknesses of } \\
\text { a bank. }\end{array}$ & $\begin{array}{l}\text { 1. The calculations are so complex } \\
\text { that parties outside the bank are } \\
\text { impossible to calculate accurately. } \\
\text { 2. This model has five separate } \\
\text { categories of assessment with a } \\
\text { maximum of } 100 \text { and a minimum } \\
\text { value of } 0 \text { so that the performance } \\
\text { of each bank is difficult to } \\
\text { distinguish and simulation is hard } \\
\text { to do. }\end{array}$ \\
\hline Z-Score & $\begin{array}{l}\text { 1. This model is able to } \\
\text { demonstrate the critical points in } \\
\text { the bank management } \\
\text { 2. This model uses standard } \\
\text { financial ratios so it is easy to be } \\
\text { calculated and understood } \\
\text { 3. This model can be used to } \\
\text { perform simulations of changes } \\
\text { in certain assumptions. }\end{array}$ & $\begin{array}{l}\text { 1. This model is not able to } \\
\text { accurately depict the performance } \\
\text { of the bank for using financial } \\
\text { standard. } \\
\text { 2. It is strongly focused on the } \\
\text { availability of NWC in a bank, } \\
\text { which is not as a main indicator. }\end{array}$ \\
\hline Bankometer & $\begin{array}{l}\text { 1. This model combines financial } \\
\text { ratios and CAEL so it enables to } \\
\text { describe the performance of a } \\
\text { bank to the right. } \\
\text { 2. It is easier to be calculated than } \\
\text { CAEL ratio. } \\
\text { 3. It forms a single index models } \\
\text { that can be used to perform } \\
\text { simulations. }\end{array}$ & $\begin{array}{l}\text { 1. This model has not been widely } \\
\text { known and not yet recognized as a } \\
\text { valid analysis of financial distress } \\
\text { for banks. } \\
\text { 2. This model has not been widely } \\
\text { tested, especially comparing the } \\
\text { prediction results between } \\
\text { insolvent and bankrupt banks. }\end{array}$ \\
\hline
\end{tabular}

From the comparison table of the three model analysis above, it can be seen that Bankometer and ZScore calculation is relatively easy thus it can be calculated by anyone with high degree of accuracy. While from the analysis results, Bankometer gives not only gives the same review as CAEL model, but it can also be used to perform simulations. Authors therefore suggest Bankometer as an analysis model to assess the financial performance of a bank mutual with the use of Z-Score as a second opinion.

\section{Conclusion}

1. Analysis by using only CAEL without calculating Management ratios from 2003 to 2011 shows that Bank Papua is predicated as healthy bank and not experiencing financial distress.

2. Analysis of Bank Papua by using the Z-Score of formula Altman, the four variables are proven that Bank Papua from 2003 to 2011 is in the position of grey area with the exception in 2007 and 2011, it is in bankrupt area. Overall, these results are contrary with the results of CAMEL calculations, so it can be concluded that Z-Score model is not suitable to be used in assessing the condition of Bank Papua. But the findings also find that in 2007 and 2011, according to Z-Score analysis is in the bankruptcy position, then the composition of the third-party fund in Bank Papua is very much dominated by current account and the number reaches the highest point during Bank Papua record. Current account is highly liquid third-party fund component that can be drawn in any quantities at anytime, so during those periods, the position of 
Bank Papua is very risky and at times, it can experience financial distress. Thus, although the Z-Score model is less suitable to be applied in Bank Papua but it is able to show the position of critical points in the history of Bank Papua management.

3. Further assessment of Bank Papua by using Bankometer model or S-Score shows that Bank Papua from 2003 to 2011 is a bank that is always predicated healthy and solvent. These results are consistent with the results of assessment with the CAMEL method thus it can be concluded that either Bankometer model or S-Score is appropriate to be used in assessing the health condition of Bank Papua.

4. The ultimate goal to be achieved from this research is to choose between the two models used and compared in this study, which is Z-Score and Bankometer model, so then the Bankometer model is a much more precise and more accurate way to assess health condition of Bank Papua because it gives similar result analysis by using CAEL assessment model.

\section{Limitations And Suggestions}

Bankometer results similarity with CAEL assessment with easier calculation technique, therefore Bankometer can be used as ratio analysis model to assess financial performance of a bank. However, this research is conducted in the form of a study of Bank Papua so that the results cannot be generalized and cannot be ascertained it can be applied equally to other Regional Development Banks. For that, more researches on the application of Bankometer model are needed on more numerous of banks and with various condition (go public or not go public; small, medium and large-scale; international, national and regional levels; experiencing financial distress or undistress).

\section{Refference}

[1] Altman, E.I. 1968. Financial Ratios, Discriminant Analysis and the Prediction of Corporate Bankruptcy. Journal of Finance 23: pp. 589-609.

[2] _ 1984. The Success of Business Failure Prediction Models: An International Survey. Journal Banking and Finance: pp. 171-198.

[3] 2000. Predicting Financial Distress of Companies: Revisiting The Z-Score and Zeta R Models. Journal of Banking and Finance, July.

[4] Christopoulos A. G., Gerantonis N. dan Vergos K, 2009. Can Altman Z-score Models Predict Business Failures in Greece? Research Journal of International Studies - Issue 12: Oktober, pp. 21-28.

[5] Duvvuri, Meherji, 2012. Financial Health of NFCL - A Z-Model Approach. IRACST-International Journal of Research in Management \& Technology, (IJRMT), ISSN: 2249-9563, Vol.2, No.1: pp. 101-106.

[6] Endri, 2009, Prediksi Kebangkrutan Bank untuk Menghadapi dan Mengelola Perubahan Lingkungan Bisnis: Analisis Model Altman's Z-Score, Perbanas Quarterly Review, vol.2, no.1. Maret 2009: pp. 34-50.

[7] Haryati, Sri, 2001. Analisis Kebangkrutan Bank. Jurnal Ekonomi dan Bisnis Indonesia, vol.16, No.4, pp.336-345.

[8] Luciana, S. A. dan Winny, Herdiningtyas. 2005. Analisis Rasio CAMEL terhadap prediksi kondisi bermasalah pada lembaga perbankan periode 2000-2002. Jurnal Akuntansi dan Keuangan, Vol 7, No. 2. November 2005: pp. 131-147

[9] Makkar, Anita and Singh, Shveta, 2012. Evaluating the Financial Soundness of Indian Commercial Banks: An Application of Bankometer. National Conference on Emerging Challenges for Sustainable Business. ISBN - 978-93-81583-46-3. pp. 118-132.

[10] Manoj P. K., (2010). Financial Soundness of Old Private Sector Banks (OPBs) in India and Benchmarking the Kerala Based OPBs: A 'CAMEL' Approach. American Journal of Scientific Research, ISSN 1450-223X Issue 11(2010), pp.132-149

[11] Mylonakis, John; Christopoulos, Apostolos G. dan Diktapanidis, Pavlos, 2011. Could Lehman Brothers' Collapse Be Anticipated? An Examination Using CAMELS Rating System. International Business Research Vol. 4, No. 2, April: pp. 11-19.

[12] Nurhidayah, 2003. Analisis Z-Score dan CAMEL dalam Mengevaluasi Tingkat Kesehatan Bank (Bank Umum yang Go Publik di BEJ). Thesis. Program Pascasarjana Universitas Brawijaya, Malang.

[13] Pongsatat, Surapol; Judy Ramage and Howard Lawrence, 2004. Bankruptcy Prediction for Large and Small Firms in Asia: A Comparison of Ohlson and Altman. Journal of Accounting and Croporate Governance, Vol. 1 No. 2, December 2004: pp. 1-13

[14] Prasad K.V.N. and Ravinder G., 2012. A Camel Model Analysis of Nationalized Banks in India. International Journal of Trade and Commerce-II ARTC Volume 1, No.1. ISSN-2277-5811: pp. 23-33.

[15] Rahmat, Triaji, 2002, Penerapan Z Score Untuk Memprediksi Kesulitan Keuangan Dan Kebangkrutan Perbankan Indonesia (Studi Kasus Kebijaksanaan Bank Indonesia Tanggal 13 Maret 1999 terhadap 18 Bank Publik). Jurnal Manajemen Investasi dan Portofolio, diakses melalui: www.geocities.com/rahmatov/Z-Score.

[16] Reddy, Sriharsha K., 2012. Relative Performance of Commercial Banks in India using Camel Approach. The International Journal's. Research Journal of Economics \& Business Studies. Volume: 01, Number: 04, Feb-2012. ISSN: 2251-1555. pp. 1-10.

[17] Sawir, Agnes 2005. Analisis Kinerja Keuangan dan Perencanaan Keuangan Perusahaan, Gramedia Pustaka Utama, Jakarta.

[18] Shar, Amir Hussain; Muneer Ali Shah and Hajan Jamali, (2010), Performance Evaluation of Banking Sector in Pakistan: An Application of Bankometer. International Journal of Business and Management, Vol. 5, No. 9; September 2010: pp. 81-86.

[19] Salim, Ubud 2011. Manajemen Keuangan Strategik. Panduan Memperbaiki Kinerja Keungan dan Profit. Universitas Brawijaya Press, Malang. ISBN. 978-602-203-043-0

[20] Thomson, James B. 1991. Predicting Bank Failures in the 1980s. Economic Review, Federal Reserve Bank of Cleveland, is sue Q I, pp. 9-20.

[21] Wilopo. 2001. Prediksi Kebangkrutan Bank. Jurnal Riset Akuntansi Indonesia, Vol 4, No. 2, Mei 2001: pp. 184-198.

[22] Zeny Arfiana dan Murtanto, 2002. Analisis Laporan Keuangan Dengan Menggunakan Rasio CAMEL dan Metode Altman Sebagai Alat untuk Memprediksi Tingkat Kegagalan Usaha Bank. Media Riset Akuntansi, Auditing dan Informasi, vol.2, No.2, Agustus 2002: pp. 44-56 